\title{
Korelasi kadar hepcidin dan asupan makanan dengan serum transferrin reseptor dan hemoglobin pada remaja stunted overweight
}

\author{
La Mani ${ }^{1,2 *}$, Siti Fatimah-Muis ${ }^{2}$, Apoina Kartini ${ }^{3}$
}

\section{ABSTRACT}

Background: Stunted overweight is associated with mild chronic inflammation. The state of inflammation will increase the expression of hepcidin, which affects the iron status of the body, besides the intake of protein, iron, and vitamin C.

Objective: To analyze the correlation of hepcidin levels and food intake (protein, iron, vitamin $C$ ) with serum transferrin receptors (sTfR) and hemoglobin in stunted overweight adolescents.

Method: The design of research was cross-sectional. The subjects were 64 adolescents stunted overweight aged 15-18 years in four high/vocational schools in the Banyumanik District, Semarang City. Measurement the level of hepcidin and sTfR was using the ELISA method and haemoglobin was using Cyanomethemoglobin method. Data on protein, iron, vitamin C intake was using the SQ-FFQ method. Bivariate analysis was using Pearson and Spearman correlation test then followed by multiple linear regression analysis.

Results: The result showed that $89.1 \%$ subjects had adequate intake of protein, $54.7 \%$ subjects had low intake of vitamin C, $76.6 \%$ subjects had low intake of iron. Hepcidin levels in all subjects were 100\% normal. There were $7.8 \%$ subjects with a low sTfR and $7.8 \%$ with a low haemoglobin level. Statistic test showed there was correlation between hepcidin with haemoglobin and $\operatorname{sTfR}\left(p_{1}=0,010 r_{1}=-0,319, p_{2}=0,001, r_{2}=0,569\right)$. From food intake, only intake iron was correlated with haemoglobin but not with sTfR. There was significant difference between the mean of haemoglobin and sTfR among girls and boys. Further analysis, showed that only hepcidin was a weak negative determinant for sTfR $\left(R^{2}=0,120\right)$. The determinant factors for haemoglobin were gender $(p=0,001)$ and hepcidin $(p=0,004)$ with the value of $R^{2}=0,577$.

Conclusion: Hepcidin correlated with sTfR and haemoglobin while iron intake only correlated with hemoglobin.

Keywords: Stunted Overweight; Hepcidin; Iron Status; Food Intake

\begin{abstract}
ABSTRAK
Latar Belakang: Stunted overweight berkaitan dengan inflamasi kronik ringan. Keadaan inflamasi akan meningkatkan ekspresi hepcidin sehingga mempengaruhi status besi dalam tubuh, selain itu asupan protein, zat besi,dan vitamin C, turut berperan terhadap status besi tubuh.

Tujuan: Menganalisis korelasi kadar hepcidin dan asupan makanan (protein, zat besi, vitamin C) dengan serum transferrin reseptor (sTfR) dan hemoglobin pada remaja stunted overweight.

Metode: Desain penelitian ini adalah cross-sectional. Subyek penelitian adalah 64 remaja stunted overweight umur 15-18 tahun di empat sekolah SMA/SMK di Kecamatan Banyumanik, Kota Semarang. Pemeriksaan kadar hepcidin dan sTfR menggunakan metode ELISA dan kadar hemoglobin menggunakan metode Cyanomethemoglobin. Data asupan protein, zat besi, vitamin C, menggunakan metode SQ-FFQ. Analisis bivariat menggunakan uji korelasi Pearson dan Spearman. Analisis multivariat menggunakan regresi linear ganda.

Hasil: Terdapat 89, $1 \%$ subyek dengan asupan protein cukup, 54,7\% subyek dengan asupan vitamin C kurang, dan 76,6\% subyek dengan asupan zat besi kurang. Semua subyek memiliki kadar hepcidin yang normal. Subyek dengan sTfR rendah sebanyak 7,8\% dan kadar hemoglobin rendah sebanyak 7,8\%. Hasil penelitian menunjukkan bahwa terdapat korelasi antara hepcidin dengan sTfR dan hemoglobin ( $\left.p_{1}=0,010 r_{1}=-0,319, p_{2}=0,001, r_{2}=0,569\right)$. Dari asupan makanan hanya asupan zat besi yang berkorelasi dengan hemoglobin $(p=0,001)$. Terdapat perbedaan rerata kadar sTfR dan hemoglobin yang signifikan antara perempuan dan laki-laki. Analisis multivariat menunjukkan bahwa hepcidin merupakan faktor determinan negatif lemah untuk $\operatorname{sTfR}(p=0,003)$ dengan nilai $R^{2}=0,120$. Faktor determinan untuk hemoglobin adalah jenis kelamin $(p=0,001)$ dan hepcidin $(p=0,004)$ dengan nilai $R^{2}=0,577$.

Kesimpulan: Hepcidin berkorelasi dengan sTfR dan hemoglobin sedangkan asupan zat besi hanya berkorelasi dengan hemoglobin
\end{abstract}

Kata kunci : Stunted overweight; Hepcidin; Status besi; Asupan Makanan

\footnotetext{
${ }^{1}$ Dinas Kesehatan Kabupaten Wakatobi Provinsi Sulawesi Tenggara. Jl. La Ode Ali Kompleks Perkantoran Manugela No 8 Wangi-Wangi, Wakatobi 93791

${ }^{2}$ Departemen Ilmu Gizi, Fakultas Kedokteran, Universitas Diponegoro. Jl. Prof. Sudarto SH, Tembalang, Semarang, Jawa Tengah 50275, Indonesia

${ }^{3}$ Departemen Gizi Kesehatan Masyarakat, Fakultas Kesehatan Masyarakat, Universitas Diponegoro. Jl. Prof. Sudarto SH, Tembalang, Semarang, Jawa Tengah 50275, Indonesia

* Korespondensi : E-mail: manimanila5741@gmail.com
} 


\section{PENDAHULUAN}

Beban ganda masalah gizi terjadi di berbagai negara berkembang, termasuk di Indonesia. Kedua masalah gizi adalah stunted dan overweight banyak ditemukan pada remaja. Prevalensi stunted pada remaja 16-18 tahun di Indonesia sebesar 31,4\% sedangkan prevalensi overweight mengalami peningkatan lebih dari lima kali lipat selama tiga tahun dari $1,4 \%$ pada tahun 2010 menjadi 7,3\% pada tahun $2013 .{ }^{1}$ Prevalensi stunted remaja 16-18 tahun di Provinsi Jawa Tengah sebesar $26,3 \%$ dan prevalensi overweight adalah 7,1\%, sedangkan Kota Semarang prevalensi stunted remaja 1618 tahun adalah $22 \%$ dan overweight adalah $14,9 \% .^{2}$

Stunted merupakan keadaan tubuh pendek atau sangat pendek yang disebabkan oleh rendahnya tingkat kecukupan asupan zat gizi dan penyakit infeksi yang berlangsung kronis. ${ }^{3,4}$ Kekurangan gizi menyebabkan terganggunya produksi hormon pertumbuhan Insulinlike Growth Factor-1 (IGF-1).,5 Adaptasi terhadap keadaan kurang gizi juga menyebabkan perubahan gen yang disebut Thrifty Gen. ${ }^{7}$ Penelitian di Brazil membuktikan bahwa remaja stunted memiliki kebutuhan energi basal dan oksidasi lemak rendah, serta peningkatan Respiratory Quotient (RQ) yang lebih tinggi sehingga penumpukan lemak lebih mudah terjadi dibandingkan remaja dengan tinggi badan normal sehingga individu stunted berisiko mengalami overweight dan obesitas. ${ }^{8}$ Penelitian di Afrika Selatan, sebesar $14,8 \%$ siswa sekolah menengah mengalami stunted dan terdapat kecenderungan overweight. ${ }^{9}$ Penelitian di Kecamatan Bangsri Kabupaten Jepara kejadian stunted pada remaja putri sebesar $23,3 \%$ dan $11,1 \%$ tergolong obesitas. ${ }^{10}$

Stunted overweight dan obesitas pada remaja berkaitan dengan inflamasi kronik derajat ringan. Keadaan tersebut ditandai dengan peningkatan kadar beberapa penanda inflamasi dalam darah yaitu Interleukin-6 (IL-6), Tumor Necrotizing Factor- $\alpha$ (TNF$\alpha$ ), C-reactive protein (CRP). ${ }^{11,12,13}$ Kondisi overweight dan obesitas terkait inflamasi sering dihubungkan dengan status besi dan hepcidin sebagai mediator kunci. ${ }^{12,13}$ Mediator inflamasi IL-6 akan memicu ekspresi transkripsi gen hepcidin pada sel hepatosit melalui jalur interaksi Janus Kinase (JAK) dengan Signal Transduser and Activator of Transcription 3 (STAT3) sehingga terjadi peningkatan kadar hepcidin. Peningkatan kadar hepcidin akan menghambat penyerapan besi sehingga akan menyebabkan gangguan proses eritropoiesis dan sintesis hemoglobin yang terkandung dalam eritrosit akan terganggu sehingga terjadi kenaikan kadar sTfR, apabila penurunan jumlah besi terus terjadi, proses eritropoiesis semakin terganggu sehingga terjadi penurunan kadar hemoglobin. ${ }^{14,15,16,17}$

Penelitian di Australia, obesitas pada remaja berkaitan dengan peningkatan kadar hepcidin yang dapat mengganggu metobolisme besi, dimana prevalensi anemia pada remaja obesitas adalah $10 \%$ dan defisiensi zat besi tanpa anemia (serum ferritin) adalah $17 \%$ dan serum transferrin reseptor adalah $6 \% .^{12}$ Penelitian di Meksiko, defisiensi besi dapat terjadi 2-4 kali pada wanita dan anak-anak obesitas. Hal ini disebabkan obesitas terjadi inflamasi sehingga terjadi peningkatan kadar hepcidin yang dapat menghambat penyerapan besi. ${ }^{18}$ Penelitian di Turki pada obesitas terjadi peningkatan kadar hepcidin dibandingkan dengan berat badan normal. ${ }^{19}$ Penelitian lain di Kota Makassar menunjukkan bahwa kadar hepcidin pada remaja SMP obesitas masih dalam batas normal sehingga tidak mempengaruhi gangguan metabolism besi. ${ }^{13}$

Faktor lain yang menyebabkan terjadinya defisiensi besi pada remaja adalah tingkat kecukupan protein, zat besi, dan vitamin $\mathrm{C}$ yang rendah. Protein berperan penting dalam transportasi dan penyerapan zat besi dalam usus halus oleh Heme Carrier Protein 1 (HCP1) ${ }^{20}$ Tingkat kecukupan protein yang rendah akan mengakibatkan transportasi zat besi terhambat sehingga terjadi defisiensi besi. ${ }^{21}$ Zat besi merupakan komponen utama pembentukan heme pada hemoglobin. ${ }^{22}$ Defisiensi besi pada remaja berhubungan erat dengan tingkat kecukupan dan bioavailabilitas zat besi yang rendah. ${ }^{23}$ Kemampuan tubuh dalam mengabsorbsi zat besi bergantung kuantitas dan bioavailabilitas besi. Bioavailabilitas besi heme sebesar 15\%-35\%, sedangkan non-heme 2\%-20\%. Vitamin C merupakan zat yang dapat meningkatkan penyerapan zat besi. ${ }^{24}$

Defisiensi besi pada remaja akan memberikan dampak negatif bagi kesehatan yaitu terjadinya gangguan pertumbuhan dan perkembangan, kelelahan, meningkatnya kerentanan tubuh terhadap infeksi, penurunan kemampuan fisik dan daya tahan tubuh serta kemampuan akademik..$^{25,26,27}$ Berdasarkan latar belakang di atas dan kurangnya kajian serta analisis pada remaja stunted overweight dihubungkan dengan penanda biomedis maupun klinik, maka mendorong peneliti untuk meneliti korelasi kadar hepcidin dan asupan makanan (protein, zat besi, vitamin C) dengan status besi pada remaja stunted overweight.

\section{BAHAN DAN METODE}

Jenis penelitian ini adalah observasional analitik dengan desain cross-sectional. Penelitian dilakukan pada bulan Maret - April 2019 di SMA 9 Semarang, SMA Islam Hidayatullah, SMK 11 Semarang, SMK Hidayah. Subyek penelitian sebanyak 64 orang yang memenuhi kriteria inklusi dan eksklusi. Kriteria inklusi yaitu remaja stunted overweight dan obesitas berusia 15-18 tahun dan tergolong stunted overweight dan stunted obesitas bila indikator TB/U dengan Z-Score < - 2 SD dan overweight berdasarkan IMT/U dengan Z-Score > 1 SD - 2 SD dan obesitas berdasarkan IMT/U dengan Z-Score > $2 \mathrm{SD}$ 
pada kelompok usia yang sama. Bersedia menjadi subyek penelitian dengan mengisi informed consent. Kriteria eksklusi yaitu menderita penyakit kronis dalam 1 bulan terakhir, menderita penyakit infeksi dalam 2-3 minggu terakhir, mengalami menstruasi dalam 1 minggu terakhir, mengonsumsi tablet besi dalam 3 bulan terakhir.

Variabel independen penelitian adalah kadar hepcidin, asupan protein, zat besi, vitamin C. Variabel dependen adalah status besi sTfR dan hemoglobin, sedangkan variabel perancu adalah jenis kelamin karena merupakan faktor yang mempengaruhi status besi. Data yang dikumpulkan dalam penelitian ini adalah karakteristik subyek, berat badan, tinggi badan, kadar hepcidin, asupan protein, zat besi, vitamin C dan sTfR serta hemoglobin. Data karakteristik subyek diperoleh melalui wawancara langsung oleh peneliti berdasarkan panduan kuesioner. Pengukuran antropometri meliputi penimbangan berat badan dan pengukuran tinggi badan dilakukan oleh enumerator terlatih. Penimbangan berat badan menggunakan timbangan digital Camry EB9003 dengan ketelitian $0,1 \mathrm{~kg}$, diletakkan dipermukaan lantai yang rata. Responden melepaskan alas kaki, berpakaian seminimal mungkin, melepaskan topi dan menanggalkan telepon genggam, jam tangan, dompet dan benda-benda lainnya yang dapat mempengaruhi hasil penimbangan. Responden dipersilahkan naik diatas timbangan digital, kedua kaki berada ditengah timbangan dan pandangan lurus kedepan. Tinggi badan diukur menggunakan microtoise Seca dengan ketelitian $0,1 \mathrm{~cm}$, ditempel didinding setinggi minimal 2 meter dengan permukaan rata. Responden diminta untuk melepaskan alas kaki kemudian berdiri tegak membelakangi dinding. Tumit, betis, pantat, bahu, kepala menempel secara baik di dinding dan pandangan lurus kedepan. Pengukuran antropometri responden dilakukan untuk menentukan status gizi berdasarkan TB/U $<-2 \mathrm{SD}, \mathrm{IMT} / \mathrm{U} 1 \mathrm{SD} 2$ $\mathrm{SD}$ dan $\geq 2 \mathrm{SD}^{28}$

Pengambilan darah dilakukan oleh tenaga analis dari laboratorium GAKY Universitas Diponegoro. Darah diambil sebanyak $3 \mathrm{cc}$ melalui vena antecubital dan dianalisis di labororatorium GAKY Undip. Kadar hepcidin diukur menggunakan metode Enzyme-Linked Immunosorbent Assay (ELISA). Kadar hepcidin dikategorikan normal $(0,079-49,4 \mathrm{ng} / \mathrm{ml})$ dan tinggi (> 49,4 ng/ml). ${ }^{12}$ Kadar serum transferrin reseptor (sTfR) subyek diukur menggunakan metode ELISA. Kadar sTfR dikategorikan normal $(1,8-4,6 \mathrm{mg} / \mathrm{L})$, rendah $(<1,8$ $\mathrm{mg} / \mathrm{L}$ ) dan tinggi (> 4,6 mg/L). ${ }^{29}$ Kadar hemoglobin subyek diukur menggunakan metode Cyanmethomoglobin. Kadar hemoglobin dikategorikan normal pada laki-laki $(13,2-17,3 \mathrm{~g} / \mathrm{dl})$, rendah $(<13,2$ $\mathrm{g} / \mathrm{dl}$ ) dan tinggi (> 17,3 g/dl) dan pada perempuan dikategorikan normal $(11,7-15,2 \mathrm{~g} / \mathrm{dl})$, rendah $(<11,7$ $\mathrm{g} / \mathrm{dl})$ dan tinggi $(>15,2 \mathrm{~g} / \mathrm{dl}) .{ }^{30}$
Pengambilan data asupan protein, zat besi, vitamin C dilakukan melalui wawancara langsung oleh enumerator terlatih menggunakan formulir SemiQuantitative Food Frequency Questionnaire (SQ-FFQ), untuk melihat kebiasaan makan dalam 3 bulan terakhir yang kemudian dikonversihkan dalam satu hari. Analisis asupan makanan menggunakan sofware Nutrisurvey 2007. Kebutuhan energi menggunakan rumus Harris Benedit untuk menghitung kebutuhan basal sesuai berat badan, tinggi badan, jenis kelamin dan umur masingmasing individu dan hasilnya dikalikan dengan faktor aktivitas fisik. Kebutuhan protein ditetapkan $15 \%$ dari kebutuhan energi tiap individu dan merupakan kebutuhan standar protein. ${ }^{31}$ Persentase kecukupan asupan protein berdasarkan perbandingan asupan protein dengan kebutuhan protein pada individu sedangkan persentase kecukupan asupan zat besi, dan vitamin C berdasarkan perbandingan asupan zat besi, vitamin $\mathrm{C}$ dengan Angka Kecukupan Gizi 2013 untuk usia 15-18 tahun. ${ }^{32}$

Penelitian ini telah mendapat persetujuan Komisi Etik Penelitian Kesehatan (KEPK) Fakultas Kedokteran Undip yang tertuang dalam Ethical Clreance No. 67/EC/FK UNDIP/III/2019 tanggal 11 Maret 2019. Tahap pertama dalam penelitian ini adalah skrining status gizi meliputi penimbangan berat badan dan pengukuran tinggi badan serta pengisian data karakteristik subyek. Tahap selanjutnya pengisian informed consent sebanyak 64 subyek yang memenuhi kriteria inklusi dan eksklusi. Tahap terakhir adalah wawancara asupan makanan dengan SQ-FFQ dan pengambilan darah untuk pemeriksaan kadar hepcidin, sTfR dan hemoglobin.

Pengolahan data statistik menggunakan SPSS 16. Analisis univariat digunakan untuk mendeskripsikan karakteristik setiap varaibel penelitian mencakup usia, berat badan, tinggi badan, nilai $\mathrm{z}$ score berdasarkan $\mathrm{TB} / \mathrm{U}$, IMT/U, asupan protein, zat besi, vitamin C, kadar hepcidin, sTfR dan hemoglobin. Analisis bivariat variabel perancu jenis kelamin terhadap variabel dependen yaitu sTfR menggunakan uji Mann Whtiney dan hemoglobin menggunakan Independen-t Test, yang sebelumnya dilakukan uji normalitas data menggunakan uji Shapiro-Wilk. Analisis bivariat variabel independen yaitu hepcidin, zat besi terhadap sTfR menggunakan uji korelasi Pearson sedangkan protein, vitamin C terhadap hemoglonin menggunakan korelasi Spearman. Analisis multivariat dilakukan untuk mengetahui variabel yang paling determinan dengan sTfR dan hemoglobin yaitu regresi linear ganda karena variabel terikat adalah numerik. Analisis multivariat dilakukan terhadap variabel yang pada analisis bivariat mempunyai nilai $p<0,25$ sesuai syarat analasis multivariat. Variabel yang masuk dalam analisis multivariat yaitu hepcidin, zat besi, vitamin $\mathrm{C}$, tanin, jenis kelamin terhadap sTfR dan 
hepcidin, protein, zat besi, fitat, tanin, jenis kelamin terhadap hemoglobin. ${ }^{33}$

\section{HASIL}

\section{Karakteristik Subyek}

Penelitian ini dilakukan pada 64 subyek pada usia 15-17 tahun. Subyek merupakan siswa-siswi SMAN 9 Semarang, SMA Islam Hidayatullah, SMKN 11 Semarang dan SMK Hidayah.

Berdasarkan Tabel 1, sebagian besar subyek stunted overweight adalah perempuan dengan usia paling banyak adalah 16 tahun. Hal ini terjadi karena perempuan mengalami menstruasi setiap bulan, dimana kondisi ini berhubungan dengan perubahan hormon estrogen dan progesteron yang meningkatkan aktivitas lipoprotein lipase dan simpanan lemak dalam tubuh.

Berdasarkan Tabel 2, sebagian besar asupan protein subyek telah memenuhi kecukupan protein yang dianjurkan 90-110\% sedangkan asupan zat besi dan vitamin $\mathrm{C}$ subyek sebagian besar belum memenuhi angka kecukupan yang dianjurkan. Kadar hepcidin pada semua subyek adalah normal sedangkan status besi sTfR sebagian besar dalam kategori normal, begitupula kadar hemoglobin subyek sebagian besar dalam kategori normal.

Tabel 1. Karakteristik Subyek

\begin{tabular}{|c|c|c|c|c|}
\hline Karakteristik & $\mathbf{n}$ & $\%$ & Rerata \pm SD & Median (min - max) \\
\hline \multicolumn{5}{|l|}{ Jenis Kelamin } \\
\hline Laki-Laki & 22 & 34,4 & & \\
\hline Perempuan & 42 & 65,6 & & \\
\hline Usia (Tahun) & & & $15,97 \pm 0,73$ & $16(15-17)$ \\
\hline 15 & 18 & 28,1 & & \\
\hline 16 & 30 & 46,9 & & \\
\hline 17 & 16 & 25,0 & & \\
\hline Status Gizi (TB/U) & & & $-2,14 \pm 0,22$ & $-2,04(-3,3-(-2,01))$ \\
\hline Sangat Pendek & 1 & 1,6 & & \\
\hline Pendek & 63 & 98,4 & & \\
\hline Status Gizi (IMT/U) & & & $2,02 \pm 0,71$ & $1,86(1,03-5,15)$ \\
\hline Overweight & 42 & 65,6 & & \\
\hline Obesitas & 22 & 34,4 & & \\
\hline
\end{tabular}

Tabel 2. Karakteristik Variabel Penelitian

\begin{tabular}{|c|c|c|c|c|}
\hline Karakteristik & $\mathbf{n}$ & $\%$ & Rerata \pm SD & Median (min - max) \\
\hline Asupan Protein & & & $108,76 \pm 11,72$ & $111(86-133)$ \\
\hline Cukup $\geq 90 \%$ & 57 & 89,1 & & \\
\hline Kurang $<90 \%$ & 7 & 10,9 & & \\
\hline Asupan Zat Besi & & & $53,02 \pm 23,94$ & $44,42(21,15-100,77)$ \\
\hline Cukup $\geq 90 \%$ & 15 & 23,4 & & \\
\hline Kurang $<90 \%$ & 49 & 76,6 & & \\
\hline Asupan Vitamin C & & & $81,46 \pm 25,60$ & $85,13(40-141,33)$ \\
\hline Cukup $\geq 90 \%$ & 29 & 45,3 & & \\
\hline Kurang $<90 \%$ & 35 & 54,7 & & \\
\hline Hepcidin & & & $14,43 \pm 5,18$ & $16(2,5-20,9)$ \\
\hline Normal $(0,079-49,4 \mathrm{ng} / \mathrm{ml})$ & 64 & 100 & & \\
\hline Tinggi (> 49,4 ng/ml) & 0 & 0 & & \\
\hline Status Besi (sTfR) & & & $2,69 \pm 0,60$ & $2,77(1,04-3,53)$ \\
\hline Normal $(1,8-4,6$ mg/L) & 59 & 92,2 & & \\
\hline Rendah $(<1,8 \mathrm{mg} / \mathrm{L})$ & 5 & 7,8 & & \\
\hline Tinggi (> 4,6 mg/L) & 0 & 0 & & \\
\hline Status Besi (Hemoglobin) & & & $14,10 \pm 1,78$ & $13,9(9,4-17,8)$ \\
\hline Laki-laki & & & $15,88 \pm 1,08$ & $15,8(13,9-17,8)$ \\
\hline $\operatorname{Normal}(13,2-17,3 \mathrm{~g} / \mathrm{dl})$ & 19 & 29,7 & & \\
\hline Rendah $(<13,2 \mathrm{~g} / \mathrm{dl})$ & 0 & 0 & & \\
\hline Tinggi (> 17,3 g/dl) & 3 & 4,7 & & \\
\hline Perempuan & & & $13,17 \pm 1,30$ & $13,25(9,4-15,6)$ \\
\hline Normal $(11,7-15,2 \mathrm{~g} / \mathrm{dl})$ & 35 & 54,7 & & \\
\hline Rendah $(<11,7 \mathrm{~g} / \mathrm{dl})$ & 5 & 7,8 & & \\
\hline Tinggi (> 15,2 g/dl) & 2 & 3,1 & & \\
\hline
\end{tabular}

\section{Analisis Faktor Perancu}


Uji bivariat faktor perancu untuk mengetahui kemaknaan beda rerata kadar hemoglobin berdasarkan jenis kelamin menggunakan Independent- $t$ Test dan untuk mengetahui kemaknaan beda rerata kadar sTfR berdasarkan jenis kelamin menggunakan uji Mann Whitney.
Berdasarkan Tabel 3 analisis bivariat laki-laki memiliki rerata kadar hemoglobin yang lebih tinggi secara bermakna dibanding perempuan $(p=0,001)$. Sedangkan perempuan memiliki rerata kadar sTfR yang lebih tinggi secara bermakna dibanding laki-laki $(p=0,042)$.

Tabel 3. Perbedaan sTfR dan Hemoglobin Berdasarkan Jenis Kelamin

\begin{tabular}{llcc}
\hline Variabel & Jenis kelamin & Deskriptif & $\boldsymbol{P}$ \\
\hline sTfR & Laki-laki & $2,5(1,04-3,53)$ & $0,042^{\mathrm{a}}$ \\
& Perempuan & $2,9(1,96-3,5)$ & \\
\hline Hemoglobin & Laki-laki & $15,88 \pm 1,08$ & $0,001^{\mathrm{b}}$ \\
& Perempuan & $13,17 \pm 1,30$ & \\
\hline
\end{tabular}

Keterangan: ${ }^{a}$ Mann whitney; ${ }^{b}$ Independent-t Test

Tabel 4. Uji Korelasi Variabel Bebas Terhadap Status Besi

\begin{tabular}{lcccc}
\hline Variabel & \multicolumn{3}{c}{ STfR } & \multicolumn{2}{c}{ Hemoglobin } & \multicolumn{1}{c}{$r$} \\
\cline { 2 - 5 } & $P$ & $r$ & $0,001^{\mathrm{d}}$ & 0,569 \\
Hepcidin & $0,010^{\mathrm{d}}$ & $-0,319$ & $0,220^{\mathrm{c}}$ & 0,155 \\
Protein & $0,578^{\mathrm{c}}$ & 0,071 & $0,001^{\mathrm{d}}$ & 0,538 \\
Zat Besi & $0,113^{\mathrm{d}}$ & $-0,200$ & $0,814^{\mathrm{c}}$ & 0,030 \\
Vitamin C & $0,189^{\mathrm{c}}$ & 0,166 & 0 \\
\hline
\end{tabular}

Keterangan : ${ }^{c}$ Korelasi Pearson; ${ }^{d}$ Korelasi Spearman

Tabel 5. Uji Regresi Linear ganda terhadap sTfR dan Hemoglobin

\begin{tabular}{lcccc}
\hline \multirow{2}{*}{ Variabel } & \multicolumn{2}{c}{ STfR } & \multicolumn{2}{c}{ Hemoglobin } \\
\cline { 2 - 5 } & $\boldsymbol{B}$ & $\boldsymbol{P}$ & $\boldsymbol{B}$ & \multicolumn{1}{c}{$\boldsymbol{P}$} \\
\hline Hepcidin & $-0,042$ & $0,003^{\mathrm{e}^{*}}$ & 0,102 & $0,004^{\mathrm{f} *}$ \\
Jenis Kelamin & & & $-2,114$ & $0,000^{\mathrm{f*}}$ \\
\hline Keterangan: ${ }^{\mathrm{e}^{*}}$ Adjusted R Square $=0,120{ }^{\mathrm{f}^{*}}$ Adjusted R Square $=0,577$ & & &
\end{tabular}

\section{Analisis Bivariat}

Analisis bivariat dilakukan untuk melihat korelasi antara variabel bebas penelitian mencakup kadar hepcidin, asupan protein, zat besi dan vitamin C terhadap variabel terikat sTfR dan hemoglobin.

Tabel 4 hasil analisis korelasi Spearman menunjukkan bahwa kadar hepcidin berkorelasi bermakna dengan $\operatorname{sTfR}(p=0,010)$ dengan koefisien korelasi negatif lemah $(r=-0,310)$ sedangkan kadar hepcidin dengan hemoglobin berkorelasi bermakna $(p=0,001)$ dengan koefisien korelasi positif sedang $(r=0,569)$. Asupan zat besi tidak berkorelasi dengan sTfR tetapi berkorelasi bermakna dengan hemoglobin $(p=0,001)$ dengan koefisien korelasi positif sedang $(\mathrm{r}=0,538)$. Hasil analisis korelasi Pearson menunjukkan asupan protein dan vitamin $\mathrm{C}$ tidak berkorelasi dengan sTfR maupun hemoglobin.

\section{Analisis Multivariat}

Analisis dilakukan untuk mengetahui variabel yang paling determinan dengan sTfR dan hemoglobin. Hasil analisis multivariat dapat dilihat pada Tabel 5 berikut

Tabel 5 menunjukkan bahwa hepcidin merupakan determinan lemah terhadap sTfR. Nilai $\mathrm{R}^{2}$ dari hasil uji regresi linear ganda adalah $12 \%$ artinya hepcidin mampu mempengaruhi sTfR sebesar $12 \%$ sedangkan $88 \%$ dipengaruhi oleh variabel lain yang tidak diteliti dalam penelitian ini. Sedangkan jenis kelamin dan hepcidin merupakan determinan kuat terhadap hemoglobin. Nilai $\mathrm{R}^{2}$ dari hasil uji regresi linear ganda adalah $57,7 \%$ artinya jenis kelamin dan hepcidin secara bersama-sama mampu mempengaruhi hemoglobin sebesar 57,7\% sedangkan $42,3 \%$ dipengaruhi oleh variabel lain yang tidak diteliti dalam penelitian ini.

\section{PEMBAHASAN}

Hepcidin merupakan sejenis hormon yang terdiri dari 25 asam amino, terutama diproduksi oleh hati dan berfungsi sebagai regulator utama dari homeostasis zat besi. ${ }^{16,17}$ Hasil analsisis uji korelasi Spearman menunjukkan kadar hepcidin berkorelasi bermakna dengan kadar sTfR $(p=0,010)$, arah koefisien korelasi negatif $(r=-0,319)$ begitupula kadar hepcidin dengan kadar hemoglobin menunjukkan korelasi bermakna $(p=0,001)$, arah koefisien korelasi positif $(r=0,569)$. Hal ini disebabkan pada penelitian ini semua subyek memiliki kadar hepcidin normal. Kadar hepcidin yang dilepaskan oleh hepatosit belum cukup banyak, intensitas yang belum kuat dan pemaparan belum 
dialami dalam jangka waktu lama sehingga kadar hepcidin tidak memberikan outcome terhadap peningkatan kadar sTfR dan penurunan kadar hemoglobin. ${ }^{17}$ Pada kondisi perdarahan atau asupan zat besi tidak mencukupi, kadar hepcidin ditemukan sangat rendah dan terkadang di bawah limit deteksi. ${ }^{34}$ Penelitian pada remaja SMP obesitas di Kota Makassar menunjukkan bahwa kadar hepcidin pada anak obesitas belum menyebabkan gangguan status besi. ${ }^{13}$

Penelitian lain pada perempuan obesitas premenopause menunjukkan mRNA hepcidin hati berkorelasi positif dengan hemoglobin $(p=0,014 \mathrm{r}=0,53)$, namun mRNA hepcidin tidak berkorelasi dengan sTfR $(p=0,82 \quad r=-0,12) \quad$ sedangkan pada perempuan premenopause berat badan normal, mRNA hepcidin berkorelasi negatif dengan $\operatorname{sTfR}(p=0,004 r=-0,63)$. Interaksi antara peradangan, penipisan besi dan peningkatan eritropoiesis pada regulasi hepcidin, sampai taraf tertentu saling menyeimbangkan satu sama lain menghasilkan hepcidin ringan tetapi tidak terlalu tinggi yang diamati pada wanita gemuk. ${ }^{35}$

Patofisiologi yang mendasari penelitian ini adalah bahwa jika terjadi rangsangan terhadap sel hati oleh mediator inflamasi seperti IL-6 yang dilepaskan karena proses inflamasi akibat obesitas maka akan terjadi peningkatan kadar hepcidin. Induksi hepcidin oleh IL-6 dimediasi oleh STAT3 yang akan menginduksi pembentukan hepcidin, selain itu, jaringan adiposit juga dapat mengekspresikan hepcidin. ${ }^{14,15}$ Ekspresi hepcidin dipengaruhi dipengaruhi oleh beberapa kondisi, seperti kadar besi di dalam sirkulasi, proses eritropoesis, hipoksia dan inflamasi. ${ }^{36}$ Pada kondisi inflamasi hepcidin akan masuk ke dalam sirkulasi untuk mengatur kadar besi. Hepcidin akan terikat dengan feroportin dipermukaan sel enterosit makrofag dan hepatosit sehingga menyebabkan degradasi feroportin. Degradasi feroportin dapat menyebabkan penyedian zat besi sirkulasi berkurang sehingga terjadi penurunan kadar besi serum yang berfungsi untuk proses eritropoesis dan menandakan adanya gangguan hemeostasis besi. Penurunan kadar besi sirkulasi akan menyebabkan gangguan pada proses eritropoesis sehingga sintesis hemoglobin yang terkandung dalam eritrosit akan terganggu sehingga akan terjadi defisiensi besi. ${ }^{16,17}$ sehingga akan terjadi kenaikan kadar sTfR, apabila penurunan jumlah besi terus terjadi, proses eritropoiesis semakin terganggu sehingga akan terjadi penurunan kadar hemoglobin. ${ }^{14,15,16,17}$

Faktor lain yang berperan dalam status besi tubuh adalah protein. Sebagian besar subyek memiliki asupan protein cukup yaitu $89,1 \%$. Rerata asupan protein subyek adalah $108,76 \pm 11,72 \%$ dan telah memenuhi kecukupan protein yang dianjurkan 90-110\%. Hasil uji korelasi Pearson, tidak terdapat korelasi antara asupan protein dengan status besi $\operatorname{sTfR}(p=0,578)$ maupun hemoglobin ( $p=0,220)$ pada remaja stunted overweight. Hasil penelitian ini sejalan dengan penelitian di Yogyakarta yang menunjukkan tidak terdapat korelasi asupan protein dengan status besi baik feritin $(p=0,761)$ maupun hemoglobin $(p=0,821)$ pada pendonor darah di Palang Merah Indonesia Kota Yogyakarta. ${ }^{37} \mathrm{Hal}$ ini karena pada penelitian ini menghitung asupan protein secara keseluruhan tanpa membedakan sumber hewani dan nabati. Salah satu bahan yang sering digunakan untuk mencukupi kebutuhan protein masyarakat Indonesia adalah berasal dari olahan kedelai. Kemampuan cerna protein nabati lebih rendah, dibandingka protein hewani. Protein nabati berkisar antara 70-90\% sedangkan protein hewani memiliki kemampuan cerna yang lebih tinggi sebesar $90-99 \% .^{38}$

Protein dalam tubuh memiliki peranan penting dalam penyimpanan dan transportasi zat besi, selain itu protein termasuk salah satu komponen yang memiliki peranan dalam pembentukan sel darah merah. Protein transferin memiliki peran dalam pengangkutan besi ke sumsum tulang untuk proses pembentukan molekul baru. ${ }^{22}$ Tingkat kecukupan protein yang rendah akan mengakibatkan transportasi zat besi terhambat sehingga terjadi defisiensi besi. ${ }^{21}$

Defisiensi besi pada remaja berhubungan erat dengan tingkat kecukupan dan bioavailabilitas zat besi yang rendah. ${ }^{23}$ Hasil penelitian menunjukkan sebagian besar subyek memiliki asupan zat besi yang kurang yaitu $76,6 \%$ dengan rentang antara 21,15-100,77\%, namun setelah dilakukan uji korelasi Spearman menunjukkan bahwa asupan zat besi berkorelasi bermakna dengan kadar hemoglobin $(p=0,00)$ pada remaja stunted overweight dengan nilai koefisien korelasi $(r=0,53)$ yang dapat diartikan arah korelasi antara variabel positif dengan kekuatan sedang. Hal ini menunjukkan bahwa semakin tinggi asupan zat besi semakin tinggi pula kadar hemoglobin remaja stunted overweight. Sedangkan asupan zat besi tidak berkorelasi dengan sTfR pada remaja stunted overweight $(p=0,113)$. Hasil penelitian ini sejalan dengan penelitian di Yogyakarta yang menunjukkan terdapat korelasi yang bermakna antara asupan zat besi dengan hemoglobin $(p=0,010)$ pada pendonor darah di palang merah Indonesia Kota Yogyakarta namun asupan zat besi tidak terdapat korelasi dengan serum feritin. ${ }^{37}$

Rendahnya asupan zat besi pada subyek disebabkan oleh pemilihan jenis makanan yaitu subyek mengonsumsi makanan dalam jumlah kecil terutama sumber makanan zat besi heme. Asupan zat besi dipengaruhi oleh kuantitas dan bioavabilitas zat besi dalam diet serta kapasitas absorbsi besi itu sendiri. Tubuh akan meningkatkan kapasitas penyerapan zat besi disaat kebutuhan meningkat. Masalah utama pemanfaatan zat besi dipengaruhi oleh dua faktor yaitu absorbsi zat besi heme dan non heme. Zat besi heme ditemukan dalam hemoglobin, mioglobin dari daging, unggas, dan ikan yang diserap secara efisien sekitar 15- 
$35 \%$, dua hingga tiga kali lebih besar daripada besi non heme dan penyerapannya kurang dipengaruhi oleh komposisi keseluruhan asupan makanan. Zat besi non heme lebih banyak ditemukan dalam sumber makanan nabati seperti sereal, kacang-kacangan, buah-buahan, sayuran. dan sedikit sumber makanan hewani jauh lebih rendah tingkat penyerapannya sekitar 2-20\%. Faktor yang meningkatkan absorbsi besi adalah vitamin $\mathrm{C}$, daging, unggas, ikan, sedangkan faktor penghambat besi terdiri dari fitat, polifenol (teh, kopi, anggur), kalsium dan asam oksalat, protein kedelai. ${ }^{24}$

Rendahnya asupan makanan yang dapat membantu penyerapan besi dan tingginya zat penghambat penyerapan besi di dalam tubuh dapat menyebabkan ketidakseimbangan besi di dalam tubuh. Jika hal tersebut berlangsung dalam jangka waktu lama, maka akan dapat menyebabkan defesiensi besi. ${ }^{39}$ Defisiensi besi pada remaja berhubungan erat dengan rendahnya tingkat kecukupan zat besi dengan bioavailabilitas serta tingginya makanan yang menghambat penyerapan zat besi. ${ }^{23}$

Vitamin $C$ merupakan zat yang dapat meningkatkan penyerapan zat besi. ${ }^{24}$ Hasil penelitian menunjukkan asupan vitamin $\mathrm{C}$ subyek sebagian besar dalam kategori kurang yaitu $54,7 \%$. Rerata asupan vitamin C subyek adalah 81,46 $\pm 25,60 \%$ dan belum memenuhi kecukupan vitamin $\mathrm{C}$ yang dianjurkan yaitu 90-110\%. Rendahnya asupan vitamin C pada penelitian ini disebabkan minimnya jumlah makanan sumber vitamin $\mathrm{C}$ yang dikonsumsi oleh subyek seperti sayuran dan buah-buahan. Hasil penelitian ini sejalan dengan penelitian di Kota Semarang dimana remaja obesitas memiliki asupan vitamin $\mathrm{C}$ yang kurang sebesar $63,3 \%$ dengan rerata $57,79 \pm 50,40 .{ }^{40}$ Penelitian di Thailand, bahwa anak overweight dan obesitas mengalami defisiensi zat gizi mikro seperti defisiensi asam askorbat (vitamin C) dan tiamin. Defisiensi vitamin C ini dapat disebabkan oleh beberapa fakor, seperti rendahnya asupan vitamin $\mathrm{C}$ akibat tingginya konsumsi junk food, kandungan vitamin $\mathrm{C}$ hilang karena proses pemanasan. ${ }^{41}$ Kandungan vitamin $\mathrm{C}$ pada makanan akan hilang sampai $80 \%$ dalam proses pengolahan, hal ini karena vitamin C mudah terdegradasi baik oleh temperatur, cahaya, maupun udara sekitar. Vitamin $\mathrm{C}$ bersifat mudah larut dalam air sehingga membuat kandungannya mudah hilang apabila terdapat luka di permukaan atau pada waktu pemotongan bahan pangan. ${ }^{42}$

Hasil uji korelasi Pearson, asupan vitamin C tidak berkorelasi dengan status besi $\operatorname{sTfR}(p=0,189)$ maupun hemoglobin $(p=0,814)$ pada remaja stunted overweight. Hal ini terjadi karena sebagian besar subyek penelitian memiliki asupan vitamin $\mathrm{C}$ dalam keadaan kurang $(54,7 \%)$. Hasil penelitian ini sejalan dengan penelitian di Yogyakarta yang menunjukkan tidak terdapat korelasi yang bermakna antara asupan vitamin $\mathrm{C}$ dengan status besi baik hemoglobin maupun feritin pada pendonor darah di palang merah Indonesia Kota Yogyakarta. ${ }^{37}$

Vitamin $\mathrm{C}$ berperan penting dalam absorbsi dan metabolisme zat besi, dengan cara mereduksi besi feri menjadi besi fero sehingga lebih mudah diabsorbsi. Vitamin $\mathrm{C}$ juga melepaskan besi dari transferrin plasma agar dapat bergabung dalam ferritin hati. Vitamin C menghambat pembentukan hemosiderin yang sukar dimobolisasi untuk membebaskan besi bila diperlukan. Absrobsi besi non-heme meningkat empat kali lipat bila ada vitamin $\mathrm{C}$. Vitamin $\mathrm{C}$ yang memadai dapat mengompensasi efek faktor penghambat zat besi. ${ }^{24} \mathrm{Hasil}$ penelitian mengenai hubungan asupan vitamin $\mathrm{C}$ dengan status besi dalam tubuh menunjukkan bahwa subyek dengan tingkat kecukupan vitamin $\mathrm{C}$ yang lebih tinggi memiliki kandungan status besi yang baik. ${ }^{43}$

Hasil analisis regresi linear ganda menunjukkan bahwa hepcidin merupakan faktor determinan negatif lemah terhadap sTfR. Nilai $R^{2}$ dari hasil uji regresi linear berganda adalah $12 \%$ artinya hepcidin mampu mempengaruhi sTfR sebesar $12 \%$ sedangkan $88 \%$ dipengaruhi oleh variabel lain yang tidak diteliti pada penelitian ini. Sedangankan jenis kelamin dan hepcidin merupakan determinan kuat terhadap hemoglobin. Nilai $R^{2}$ dari hasil uji regresi linear ganda adalah $57,7 \%$ artinya jenis kelamin dan hepcidin secara bersama-sama mampu mempengaruhi hemoglobin sebesar $57,7 \%$ sedangkan $42,3 \%$ dipengaruhi oleh variabel lain yang tidak diteliti pada penelitian ini.

Hemoestasis besi di dalam tubuh dapat tercapai apabila terdapat pengaturan absorpsi, distribusi, penyimpanan dan daur ulang besi. Salah satu zat terpenting dalam regulasi kadar besi di dalam tubuh adalah hepcidin. Hepcidin berfungsi mengatur regulator utama dari homeostasis besi. Jika terjadi stimulasi terhadap sel hati oleh mediator IL-6, produksi hepcidin akan meningkat. ${ }^{15,16,17}$ Peningkatan kadar serum hepcidin akan menghambat pelepasan simpanan zat besi di dalam makrofag dan hepatosit serta mencegah pergerakan absorpsi zat besi melalui ferroportin di enterosit kesirkulasi. Sekuestrasi zat besi di makrofag dan penurunan absorpsi zat besi sehingga akan menyebabkan penurunan simpanan besi tubuh, kadar sTfR akan meningkat, bila penurunan simpanan besi berlangsung dalam jangka panjang dapat terjadi anemia defisiensi besi dengan cara menurunkan ketersedian besi untuk proses eritropoiesis. ${ }^{17,44}$ Keseimbangan status besi manusia diatur secara mendasar oleh tingkat eritropoiesis dan simpanan besi tubuh. ${ }^{45,46}$ Konsentrasi sTfR dalam plasma mencerminkan tingkat eritropoiesis, yang meningkat ketika aktivitas eritropoiesis ditingkatkan dan menurun dengan berkurangnya aktivitas eritropoiesis. ${ }^{45}$

Remaja perempuan berisiko mengalami defisiensi besi dibandingkan dengan remaja laki-laki, karena remaja perempuan mengalami menstruasi setiap bulan 
sehingga banyak kehilangan zat besi. Remaja perempuan stunted overweight dalam usia produktif membutuhkan zat besi yang lebih banyak dibandingkan laki-laki, bila kecukupan zat besi tidak terpenuhi, akan terjadi penurunan cadangan besi. ${ }^{25}$ Dalam keadaan cadangan besi dalam tubuh berkurang kadar sTfR meningkat. Keseimbangan negatif ini bila berlangsung lama, cadangan besi dalam tubuh akan semakin menipis sehingga terjadi penurunan kadar hemoglobin yang berlanjut pada anemia defisiensi besi. ${ }^{22,42,43}$

Kelebihan penelitian ini adalah dapat memberikan informasi dan kajian kadar hepcidin, asupan protein, zat besi dan vitamin $\mathrm{C}$ dalam kaitanya dengan status besi sTfR dan hemoglobin pada remaja stunted overweight dan obesitas sehingga dapat digunakan sebagai upaya dalam pencegahan dan penanggulangan defisiensi besi pada remaja stunted overweight dan obesitas. Kekurangan dalam penelitian ini adalah tidak dilakukan pemeriksaan kadar Hs-CRP dan IL-6 untuk mengetahui inflamasi yang mempengaruhi kadar hepcidin dan status besi serum transferrin reseptor dan hemoglobin pada remaja stunted overweight.

\section{SIMPULAN}

Hepcidin berkorelasi dengan sTfR dan hemoglobin sedangkan asupan zat besi hanya berkorelasi dengan hemoglobin.

\section{SARAN}

Penelitian selanjutnya, sebaiknya mempertimbangkan variabel Hs-CRP dan IL-6, untuk melihat terjadinya inflamasi yang mempengaruhi kadar hepcidin. Hasil penelitian dapat diteruskan ke sekolah agar dimasukan dalam mata pelajaran biologi atau pelajaran olahraga dan kesehatan jasmani tentang pentingnya menjaga makanan dan berat badan dalam batas normal pada remaja yang overweight dan obesitas.

\section{UCAPAN TERIMA KASIH}

Ucapan terima kasih ditujukan kepada semua responden di SMAN 9 Semarang, SMA Islam Hidayatullah, SMKN 11 Semarang dan SMK Hidayah atas partisipasinya dalam penelitian.

\section{DAFTAR PUSTAKA}

1. Balitbang Kemenkes RI. Riset Kesehatan Dasar. Jakarta: Balitbang Kemenkes RI; 2013.

2. Santoso B, Sulistiowati E, Tuti S, Lamid A. Riset Kesehatan Dasar Provinsi Jawa Tengah. Jakarta: Balitbang KemenKes RI; 2013.

3. Weisa AS. Global Nutrition Targets 2025: Stunting Policy Brief. Geneva: WHO; 2014.

4. Martin VJ, Floronzio TM, Grillo LP, Franco MC,
Martins PA, Clemente AP et al. Long-lasting effects of undernutrition. Int $J$ Environ Res Public Health. 2011;8:1817-1846.

5. Prendergast AJ, Rukobo S, Chasekwa B, Mutasa K, Ntozini R, Mbuya MN et al. Stunting is characterized by chronic inflammation in zimbabwean infants. PLoS One. 2014;(2):1-11.

6. Syed S, Karim P, Manji KP, McDonald CM, Kisenge $\mathrm{R}$, Aboud $\mathrm{S}$ et al. Biomarkers of systemic inflammation and growth in early infancy are associated with stunting in young Tanzanian children. Nutrients. 2018;10:1-14.

7. Baig U, Belsare P, Watve M, Jog M. Can Thrifty Gene (s) or Predictive Fetal Programming for Thriftiness Lead to Obesity? J Obes. 2011;2011:1-11.

8. Hoffman DJ. Growth retardation and metabolic programming: implications and consequences for adult health and disease risk $\widetilde{Q}, \complement_{Q}$ Retardo do crescimento e programac, ão metabólica: implicac , ões e consequências para a saúde do adulto e o risco de doenc, as. J Peditria. 2014;90(4):325-328.

9. Mukuddem-Petersen J, Kruger HS. Association between stunting and overweight among 10-15-y-old children in the North West Province of South Africa: The THUSA BANA Study. Int J Obes. 2014;(7):842851.

10. Saraswati AT, Sulchan M. Kejadian sindrom metabolik pada remaja putri stunted obesity di Pedesaan Jepara. journl if Nutr Coll. 2016;5(3):192197.

11. Kruger HS, Pretorius R, Chutte AE. Stunted, adiposity, and low-grade inflammation in African adolescents from a township high school. Nutr Elsevier Ltd. 2010;26:90-99.

12. Cheng HL, Bryant CE, Rooney KB, Steinbeck KS, Griffin HJ, Petocz $P$ et al. Iron, Hepcidin and Inflammatory Status of Young Healthy Overweight and Obese Women in Australia. PLoS One. 2013;8(7):1-6.

13. Ridha NR, Daud D. Hubungan Kadar Hepcidin dengan Status Besi pada Inflamasi Akibat Obesitas. Sari Pediatr. 2014;16(3):161-166.

14. Hintze KJ, McClung JP. Hepcidin: A critical regulator of iron metabolism during hypoxia. Adv Hematol. 2011;(8):1-7.

15. Diedra M W, Andrews. NC. Interleukin-6 induces hepcidin expression through STAT3. Blood. 2006;108(9):3204-3209.

16. Ganz T, Nemeth E. Hepcidin and iron homeostasis. Biochim Biophys Acta. 2012;1823(9):1434-1443.

17. Ganz T. Hepcidin and iron regulation, 10 years later. Blood. 2011;117(17):4425-4433.

18. Cepeda-Lopez, Osendarp SJ, Boonstra AM, Aeberli I, Salazar FG, Feskens E et al. Sharply higher rates of iron deficiency in obese Mexican women and children are predicted by obesity-related inflammation rather than by differences in dietary iron intake. Am J Clin Nutr. 2011;93:975-983.

19. Sal E, Yenicesu I, Celik N, Pasaoglu H, Celik B, 
Pasaoglu OT, Kaya Z, Kocak U, Camurdan O, Bideci A CP. Relationship between obesity and iron deficiency anemia: is there a role of hepcidin? Hematolgy. 2018;23(8):542-548.

20. Knutson D. Iron transport proteins: Gateways of cellular and systemic iron homeostasis. JBiolChem. 2017;292(31):12735-12744.

21. Hassan F, Salim S, Humayun A. Prevalence and Determinants of Iron Deficiency Anemia in Adolescents Girls of Low Income Communities in Lahore. Ann King Edward Med Univ. 2017;23(2):116125.

22. Zimmermann MB, FHurrell R. Nutritional iron deficiency. Lancet. 2007;370:511-520.

23. Olumakaiye MF. Adolescent Girls With Low Dietary Diversity Score Are Predisposed to Iron Deficiency in Southwestern. ICAN. 2013;5(2):85-91.

24. Hurrel R, Engli I. Iron bioavailability and dietary reference values. Iron Bioavailab Diet Ref values 1-4. 2010;91:1461-1467.

25. Brown JE. Nutrition Through The Life Cycle. Fourth Edi. USA: Wadsworth; 2011.

26. More S, Shivkumar V., Gangane N, Shende S. Effects of iron deficiency on cognitive function in school going adolescent females in rural area of central India. Anemia. 2013;2013:1-5.

27. Hassan TH, Badr MA, Karam NA, et al. Impact of iron deficiency anemia on the function of the immune system in children. Med (United States). 2016;95(47):1-5.

28. Kemenkes RI. Standar Antropometri Penilaian Status Gizi Anak. Jakarta: Kementerian Kesehatan RI; 2011.

29. Sumarmi S, Puspitasari N, Handajani R, Wirjatmadi B. Underweight as a Risk Factor for Iron Depletion and Iron- Deficient Erythropoiesis among Young Women in Rural Areas of East Java, Indonesia. Mal J Nutr. 2016;22(2):219-232.

30. WHO. Haemoglobin Concentrations for the Diagnosis of Anaemia and Assessment of Severity. Geneva, Switzerland: Department of Nutrition for Health and Development (NHD); 2011.

31. Almatsier S. Penuntun Diet. Baru. Jakarta: Gramedia Pustaka Utama; 2006.

32. Kemenkes RI. Pedoman Gizi Seimbang. Jakarta: Kementerian Kesehatan RI; 2015.

33. Dahlan MS. Statistik Untuk Kedokteran Dan Kesehatan. Jakarta: Salemba Medika; 2011.
34. Kroot JJC, Tjalsma H, Fleming REF, Swinkels DW. Hepcidin in human iron disorders: Diagnostic implications. Clin Chem. 2011;57(12):1650-1669.

35. Tussing-humphreys M, Nemeth E, Fantuzzi G, et al. Elevated Systemic Hepcidin and Iron Depletion in Obese Premenopausal Females. Obesity. 2009;18(7):1449-1456.

36. Chaston T, Chung B, Mascarenhas M, et al. Evidence for differential effects of hepcidin in macrophages and intestinal epithelial cells. Hepatology. 2008;57:374382.

37. Satwika KA. Hubungan antara asupan protein, vitamin $\mathrm{C}$, zat besi dan inhibitor absorbsi besi dengan status besi pada pendonor darah di Palang Merah Kota Yogyakarta. Skripsi. 2016.

38. Whitney E, Rolfes S. Understanding Nutrition. Fourtin Editon. California: Cengage Learning; 2016.

39. Abbaspou N, Hurrell R, Kelishadi R. Review on iron and its importance for human health. J Res Med Sci. 2014;19:164-174.

40. Nisa AK, Nissa C, Probosari E. Perbedaan asupan gizi dan kadar hemoglobin pada remaja perempuan obesitas dan tidak obesitas. JNutrition Coll. 2019;8(1):21-28.

41. Densupsoontorn N, Jirapinyo P, Kangwanpornsiri C. Micronutrient deficiencies in obese Thai children. Asia Pac J Clin Nutr. 2013;22(3):497-503.

42. Begum S,Faiaz M, Ahmed RM. Efffect of Cooking Temperature and Storage Period on Preservation of Water Soluble Vitamin C Content in Citrus Macroptera and Moringa Oleifera Lunk. Asian J Foof Agro-Industry. 2009;2(03):255-261.

43. Péneau S, Dauchet L, Vergnaud A-C, et al. Relationship between iron status and dietary fruit and vegetables based on their vitamin $\mathrm{C}$ and fiber content. Am J Clin Nutr. 2008;87:1298-1305.

44. Urrechaga E, Borque L, Escanero JF. Biomarkers of Hypochromia : The Contemporary Assessment of Iron Status and Erythropoiesis. Biomed Res Int. 2013;2013:1-8.

45. Choi JW, Pai SH. Associations between serum transferrin receptor concentrations and erythropoietic activities according to body iron status. Ann Clin Lab Sci. 2003;33(3):279-284.

46. Wallace D F. The Regulation of Iron Absorption and Homeostasis. Clin Biochem Rev. 2016;37(2):51-62. 